\title{
Effect of External Post-Tensioning Strengthening Technique on Flexural Capacity of Simple Supported Composite Castellated Beam
}

\author{
Hayder A. Hashim ${ }^{1, \mathrm{a}}$ and Alaa H. Al-Zuhairi ${ }^{1, \mathrm{~b}}$ \\ ${ }^{1}$ Department of Civil Engineering, University of Baghdad, Baghdad, Iraq \\ ah.alameedy78@gmail.com, balaa@coeng.uobaghdad.edu.iq
}

\begin{abstract}
This research is carried out to study the effect of the external post-tensioning technique on the flexural capacity of simply supported composite castellated beam experimentally. In this research, seven composite castellated beams having the same dimensions and material properties were cast and tested up to failure by applied two concentrated loads at $700 \mathrm{~mm}$ from each end. Two external strands of $12.7 \mathrm{~mm}$ diameter were fixed at each side of the web of strengthening beams and located at depth $180 \mathrm{~mm}$ from top fiber of the section (dps) at each end of the beam. The strands have been tensioned by using a hydraulic jack with a constant stress of $100 \mathrm{MPa}$. This research aims to study the effect of the strengthening by different shapes of strand profiles of external post-tensioning techniques on the flexural capacity of the composite castellated beam. These beams were divided into three groups. Each group contained two composite castellated beams while $7^{\text {th }}$ composite castellated beam kept without strengthening by external post-tensioning technique As control beam. The first group included two beams with straight strand profile of external Post-tensioning. The second group included two beams with a triangular strand profile of external post-tensioning. The third group included two beams with a trapezoidal strand profile of external post-tensioning. All composite castellated beams were simply supported, and all of them were fully shear connections between the concrete slab and steel girder. All beams included the 16 castellated openings and were stiffened by six stiffener plates welded on the web of castellated beams. Three stiffener plates are welded on each side of the web. Two of these stiffener plates welded at the middle of the beam, and four of them welded at locations under the loads. The experimental results of this research were increasing $5.43 \%$ in load capacity of an average of the straight profile of composite castellated beams, increasing $18.92 \%$ in load capacity of an average of triangular profile composite castellated beams, and increasing $20.71 \%$ in load capacity of the trapezoidal profile of composite castellated beams. All the above results were compared with control beams.
\end{abstract}

Keywords: External post-tensioning; triangular profile; trapezoidal profile; straight post-tensioning; castellated beam.

\section{Introduction}

It should be recognized that rehabilitation techniques include three subgroup techniques[1]; that are: (a) repairing technique: this type of rehabilitation become the right choice if the non-structural or some structural members exposed to damage to obtain the pass their performance before the damage, there are many reasons caused the damage such as earthquake, blast, fire, corrosion, accidents by vehicles [2]. (b) retrofitting technique: if the existing sections need to change in designed performance, this process is done [3]. (c) strengthening approach: if the structures need to increase the reinforced due to different reasons such as financial or sociological problems [2]. The selection of the above methods depends on several following parameters: required strength, required stiffness, required deflection, required ductility, and energy absorption. Complete replacement of the deficient construction structure instead of rehabilitation must depend on an accurate study to balance the cost of the new structure and rehabilitated structure, the duration of construction of them, and their quality. In other word including the feasibility of project, because of this decision is final decision, therefore the knowledge of reasons of rehabilitation become very necessary. These reasons as briefly [4]:

- There are some errors in the original design of the structure. 
- The maintenance does not at the required level or there is no maintenance.

- The function of the whole structure or some members of the structure is changed

- The blasts have occurred in or nearly from the structure.

- In bridges and transportation structures, increasing the traffic volume.

- In some cases, it is occurring natural disasters such as earthquakes, fires, and volcanoes.

- All other unnatural fires.

- Design code is updated.

\section{External Post-Tensioning Technique}

This research deal with one of the rehabilitation methods that is strengthening. The strengthening technique aims to increase the capacity of member in the existing structure to carry the existing of subjected load which are insufficient due to the damage caused by existing load corresponding with defect in the design, changing in the function of a structural member or deteriorated members. To achieve the above aim, the designer may be choosing one of the following methods: external postTensioning, concentric or existence steel braces, shear walls, masonry infilled, base isolator, steel jacketing [5], FRP laminates or FRP wrapping [1], concrete armor and frictional-hysteretic and viscoelastic dampers [2]. The external post-Tensioning technique is placed the prestressed tendon outside of the structural section and the prestressing force transferred to the structural section by deviators and anchorages [6]. This technique is spread widely in the many countries rapidly because of its advantages.

The structures resulting after applied external post-Tensioning tendons have behavior different from original structures because the new structures have different stiffness, capacity, and other details relative to the structures. This method includes to applied an axial load combined with bending moment to improve the flexural capacity and/or shear capacity of the structural elements [7]. There are a lot of benefits from the usage of this method depends on the characteristics of it. For example, the increase of stiffness due to this technique's application leads to reduced in-service deflection and vibration, which means improved serviceability. Also, the large deflection or sag that present in the girder without external prestressed can be removed. So, it can be changed the behavior of the structure such as providing continuity across support, changing the series of simple support beams to one continuous beam or providing continuity across an unsupported joint, the joint two cantilever spans [6].

Castellated Beam. The castellated opening referred to the hexagonal, Octagonal or square shape of openings [8]. The castellation term came from "castle battlements" because of the presence of similarity in the geometric shape between them [9]. The castellated beam is the beam that contains holes in the web of it, these holes almost at constant distances. These holes take hexagonal, Octagonal, and square shapes, while in case these holes take circular shape, the beam calls a "cellular beam" [10]. Usually, the castellated beam is made from I rolled shape beam by cutting the web of it as a zigzag cutting line longitudinally to produce two parts and move one part to another, and re-welding together to make castellated openings in the web of the beam. Nearly in 1930 was the first try to use this technique in steel structures. Earlier, this technique was used widely in Europe more than in North America; after that, because of the machines of cutting and welding were developed, the castellated beams became used widely in North America and Europe. This development of machines led to a reduction in the cost of product castellated beams and then used in floor system in different regions [11]. The castellation process led to an increase in the depth of the beam for the same weight compared with the origin beam; therefore, the stiffness of the castellated beam would increase. Sometimes needed to use increment plate between two parts to increase the beam depth to increase the stiffness of the beam. These plates welded the highest points of the bottom part and lowest points of the top part. For these reasons, the castellation beam was considered a suitable technique for long spans. Therefore, the castellated beam was considered a good choice for common buildings such as 
(commercial and industrial buildings) to adequate stiffness for resisting deflection that happened because of long spans for these constructions.

\section{Design Castellated Beam's Parameters}

There are several geometric designed parameters taken in mind through the design the castellated beam. Many controls explain the method and design parameters that should be into account. One of these controls is the Knowles design method. The following relationships defined the parameters shown in Figures 1 and 2 [10].

$$
\begin{aligned}
& a=\frac{1}{4}\left(\rho-2 c \cot 60^{\circ}\right) \\
& a=\frac{1}{4}\left(\rho-2 c \cot 60^{\circ}\right) \\
& \mathrm{b}=\mathrm{c} \cot 60^{\circ} \\
& \mathrm{c}=0.5 \mathrm{D}_{\mathrm{s}} \\
& \rho=1.08 \mathrm{D}_{\mathrm{s}} \\
& \varnothing=60^{\circ} \\
& \mathrm{D}_{\mathrm{c}}=\mathrm{D}+\mathrm{c}=\mathrm{D}=0.5 \mathrm{D}_{\mathrm{s}} \\
& \mathrm{h}=\mathrm{D}_{\mathrm{c}}-2 \mathrm{C}_{\mathrm{x}}
\end{aligned}
$$

Where

Ds is the serial depth of the original section.

$\mathrm{D}$ is the actual depth of the original section.

$\mathrm{a}$ is half hexagonal side.

$\mathrm{b}$ is the horizontal projection of an oblique hexagonal side.

$\mathrm{c}$ is the vertical projection of an oblique side.

$\Phi$ is the angle of the oblique side with the horizontal axis.

$\mathrm{B}$ is the width of the flange.

$\mathrm{T}$ is the thickness of the flange.

$\mathrm{C}_{\mathrm{x}}$ is the distance from top fiber to end fillet in the web.

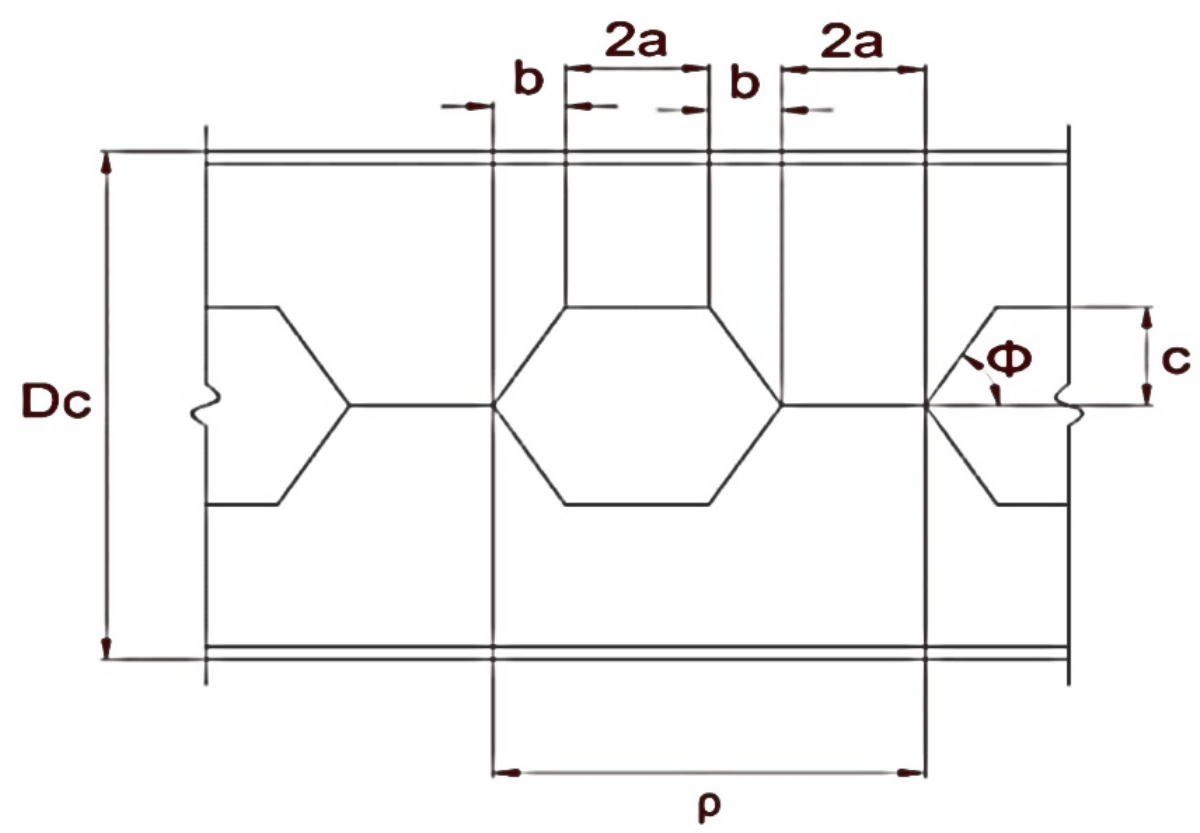

Figure 1. Parameters of castellated beam. 


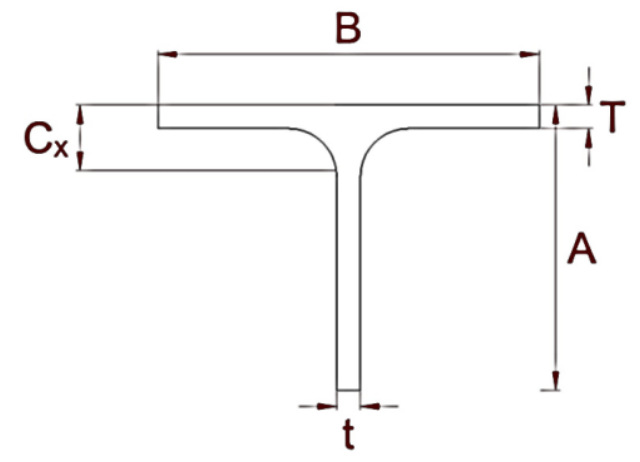

Figure 2. Cross-section of the castellated beam.

\section{Experimental Work}

In this study, taken the I beam (w-shape $6 \times 16)[12,13]$, then made castellated expands to obtain castellated beam with sixteen castellated openings, the depth of castellated steel girder was (198 mm). Channel shear connectors welded on top flange of steel girder with longitudinal spaces $(200 \mathrm{~mm})$ to full connection composite beam. Three stiffener plates with thickness $8 \mathrm{~mm}$ welded on web steel at distances $700 \mathrm{~mm}, 1100 \mathrm{~mm}$, and $1500 \mathrm{~mm}$ from the left end of the beam. The concrete slab cast with dimensions $(2100 \mathrm{~mm})$ in length, $(400 \mathrm{~mm})$ in width and $(80 \mathrm{~mm})$ in thickness. The concrete slab is reinforced with a single layer reinforced rebar in two directions. In the longitudinal direction, the reinforcement was $(\varnothing 8 \mathrm{~mm})$ deformed rebar with $90 \mathrm{~mm}$ space (center to center), and in the transverse direction was (8@200), the spaces (center to center). The strands used in this study to fix out of the section were $12.7 \mathrm{~mm}$ in diameter, this strand anchored from each end in two end plates with $(20 \times 400 \times 300 \mathrm{~mm})$. There were seven composite castellated beams, one of these beams was a control $(\mathrm{CON})$ beam that means this beam without external post-tensioning. The second (STR1) and third (STR2) beams were with straight profile strands. The $4^{\text {th }}$ composite castellated beam (TRI1) and $5^{\text {th }}$ composite castellated beam (TRI2) were with triangle profile strands. Finally, the $6^{\text {th }}$ composite castellated beam (TRAP1) and $7^{\text {th }}$ composite castellated beam (TRAP2) were with trapezoidal profile strands. All beams were simply supported beams and applied two loads at $700 \mathrm{~mm}$ from each end of the beam.

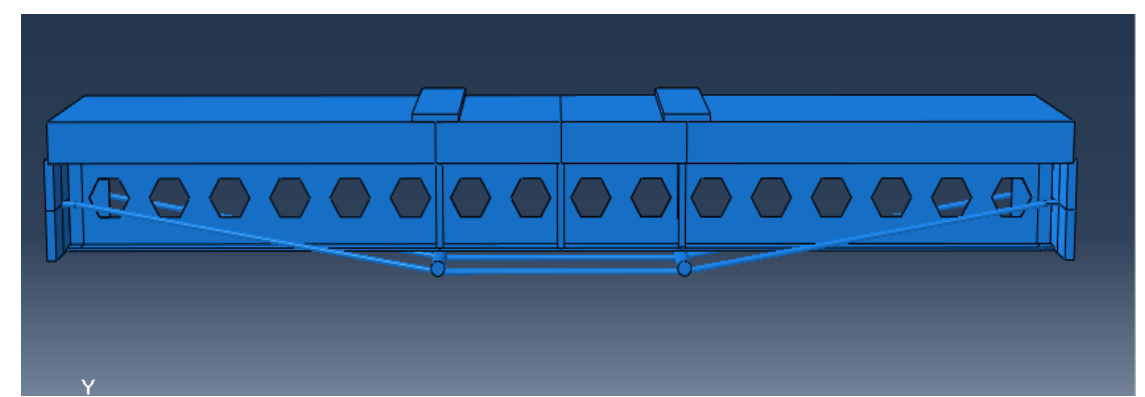

Figure 3. Composite castellated beam with trapezoidal profile beam.

\section{Experimental Results at Mid Span of Beam}

The result of the control composite castellated beam (without external post-tensioning) showed that the ultimate load capacity of the composite castellated beam at mid-span was $263.34 \mathrm{kN}$ as shown in Figure 4. This value is used in comparison with other results of composite castellated beams. The straight strand profile of composite castellated beams was tested two beams then obtained the average results of them in Figure 5. These results showed that the ultimate load capacity was $279.80 \mathrm{kN}$, which means the load capacity increased $5.43 \%$ by external post-tensioning. Two composite castellated beams with a triangular profile of strands were tested, then obtained the average results in Figure 6. These results showed that the ultimate load capacity was $327.27 \mathrm{kN}$, which means the load capacity increased $23.339 \%$ by external post-tensioning. Two composite castellated beams with 
trapezoidal profile of strands were tested, then obtained the average results of them in Figure 7 . These results showed that the load capacity was $334.64 \mathrm{kN}$, that means the load capacity increased 26.118\% by external post-tensioning.
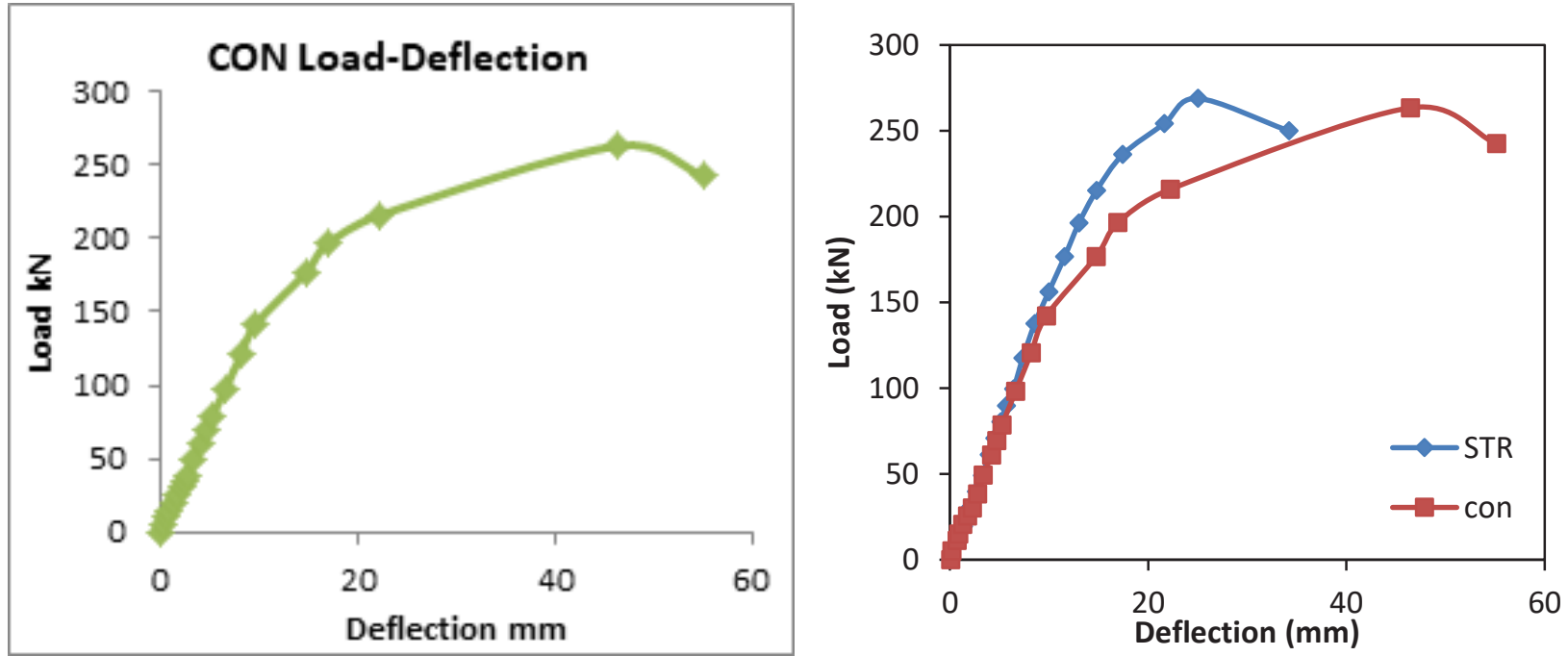

Figure 4. CON load-deflection curve.

Figure 5. Average of STR load-deflection curve.
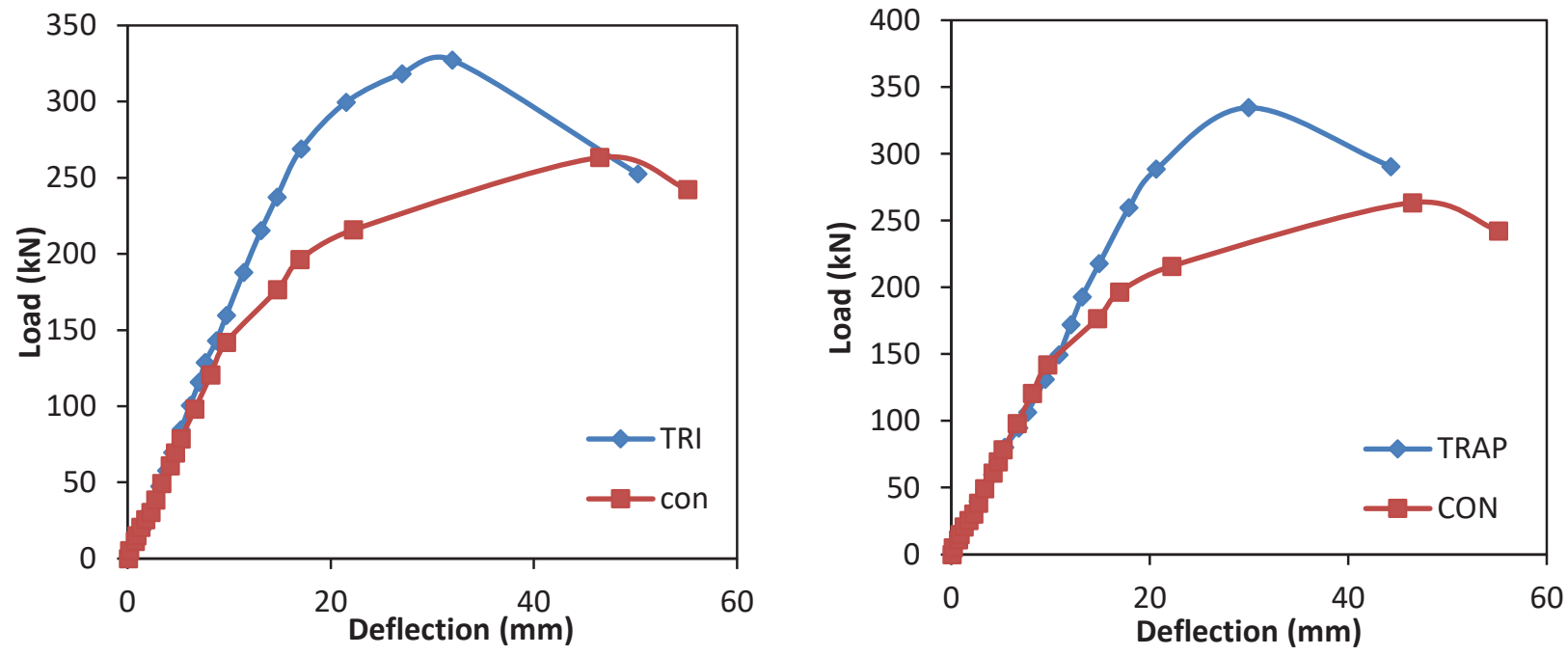

Figure 7. Load-deflection curves for trapezoidal beams.

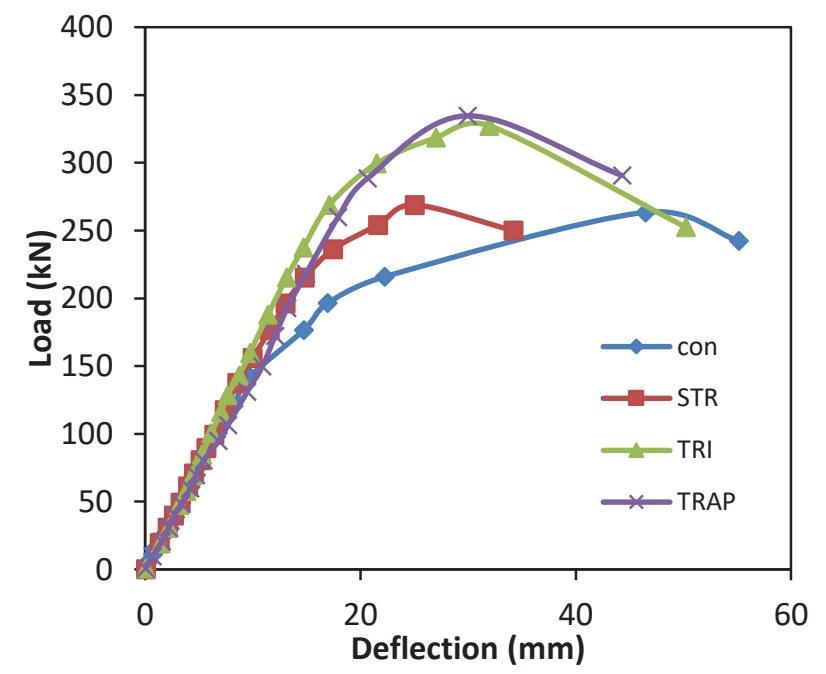

Figure 8. Load-Deflection for all strand. 
It was possibly noted from Figure 8, that the composite castellated beam with a trapezoidal profile of strand (TRAP) was given the highest value of ultimate load capacity. The composite castellated beam with a triangular profile of strand (TRI) was given a value of ultimate load capacity less than TRAP, the composite castellated beam with a straight profile of strand (STR) was given value less than TRI, and the control beam was the lowest value of ultimate load capacity.

\section{Discussion and Conclusions}

According to the above results, it was concluded that in composite castellated beam with the external post-tensioning technique with a trapezoidal profile shape was increasing the load capacity more than triangular profile and straight profile of external strand that used in external posttensioning. Simultaneously, the triangular profile strand was increasing the load capacity more than the straight profile of strand used in external post-tensioning. These conclusions were caused by the development of vertical components of external post-tensioning force toward up against the applied load. These components in case trapezoidal strand shape developed in two positions relatively with cross sections under every applied loads as shown in Figure 9.

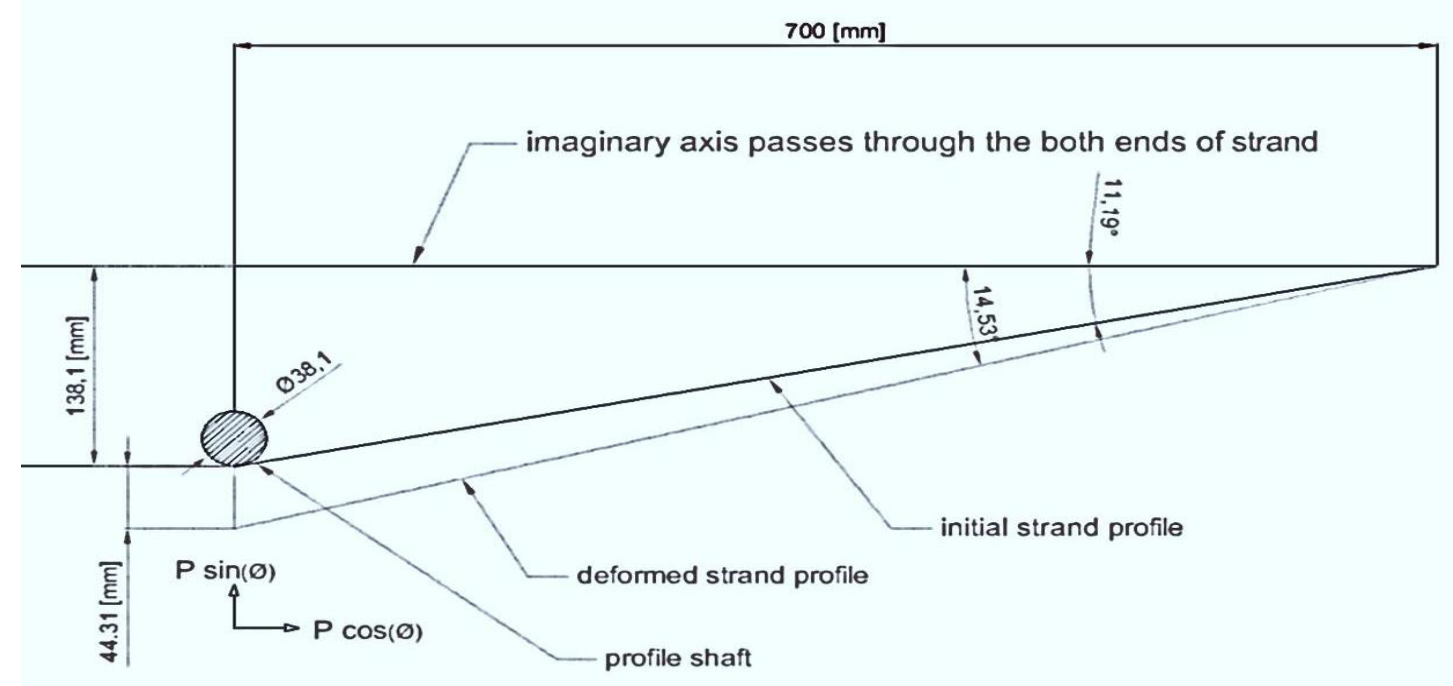

Figure 9. FBD of TRAP initial and deformed profile and its angle with a horizontal axis.

The vertical component was affected by two factors: the first factor was the value of the initial pull force applied on the strand. The second factor was the initial angle of the strand with the horizontal axis. This angle increased with an increase in the vertical load on the beam because deflection occurred. In this case, the initial angle was $\left(11.19^{\circ}\right)$ and the vertical component equal (2Psin (11.19)), which means the vertical component equal $(0.388 \mathrm{P})$ where $\mathrm{P}$ : is the prestressing force that is applied on the strand. It was observed that the value of the vertical component multiplies by (2) because the present two strands are on both sides of the composite castellated beam. On the other hand, the final angle after the deformed beam was $\left(14.53^{\circ}\right)$ and the vertical component became (2Psin(14.53)), which means the vertical component equal $(0.502 \mathrm{P})$. The calculation of the vertical component was showed the range value between (38.8$50.2 \%$ ) from P-value. Therefore, this component should be considered, while in triangular strand shape developed in one position relatively with a cross-section of the composite castellated beam as shown in figure (10). 


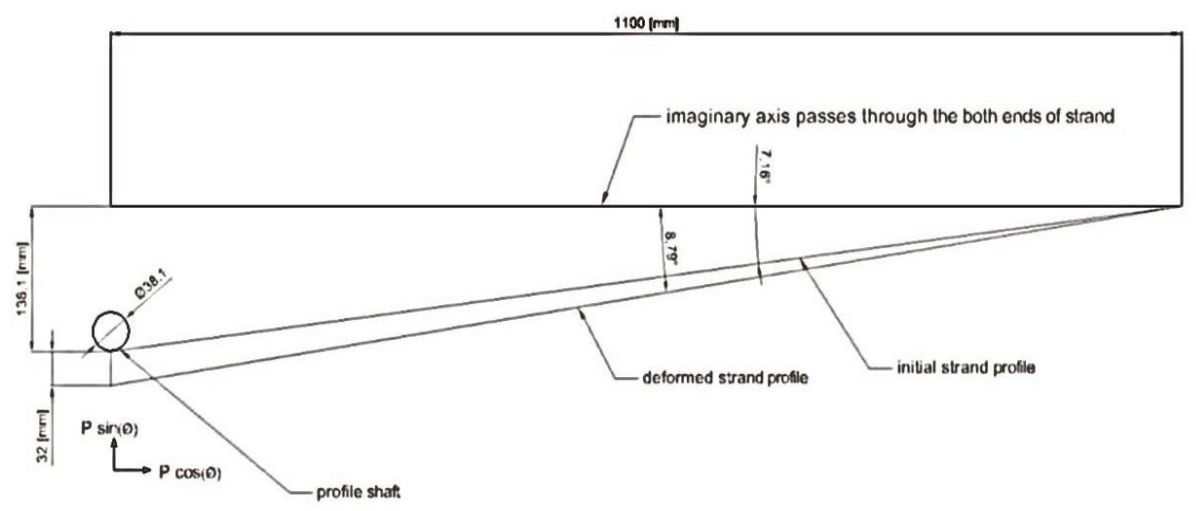

Figure 10. FBD of TRI initial and deformed profile and its angle with a horizontal axis.

In TRI, the initial angle was $\left(7.16^{\circ}\right)$, and the vertical component equal (2Psin (7.16)) that means the vertical component equal $(0.25 \mathrm{P})$ the final angle after the deformed beam was $\left(8.79^{\circ}\right)$ and the vertical component equal $(2 \mathrm{P} \sin (8.79))$ that means the vertical component became $(0.306 \mathrm{P})$. The range of component value of TRI was (25-30.6\%) from P-value; therefore, the vertical component should be considered. At the same time, the straight strand shape did not develop any vertical component.

\section{References}

[1] Ozcebe, G., Ersoy, U., Tankut, T., Akyuz, U. and Erduran, E., 2004, August. Rehabilitation of existing reinforced concrete structures using CFRP fabrics. In Proceedings of 13th World Conference on Earthquake Engineering (pp. 1-6).

[2] Ostad-Ali-Askari, K.., Singh, V.P., Dalezios, N.R. and Crusberg, T.C., 2018. Methods of strengthening reinforced concrete structures and introduction to the method of FRP sheet reinforcement. The Architects International, 1(1-2018), pp.1-5.

[3] KOÇAK, A., Onal, M. and Sonmez, K.A.A.N., 2007. Repairing and strengthening methods for RC structural members. 6th International Conference on Fracture Mechanics of Concrete and Concrete Structures, Catania, İtalya

[4] Jumaat, M. Z. and Alam, M.A., 2010. Experimental and numerical analysis of end anchored steel plate and CFRP laminate flexurally strengthened RC beams. International Journal of the Physical Sciences, 5(2), pp.132-144.

[5] Alam, M. A., Nouri, K., Jumaat, M. Z. and Muda, Z. C., 2015, April. Flexural strengthening of reinforced concrete beam using jute rope composite plate. In The 3rd National Graduate Conference, Putrajaya (pp. 8-9).

[6] Hong, S., Cho, D. and Park, S.K., 2016. Application of a new anchorage towards the flexural strengthening of RC rectangular beams with external steel tendons. Applied Sciences, 6(5), p.119.

[7] El-Zohairy, A. and Salim, H., 2017. Parametric study for post-tensioned composite beams with external tendons. Advances in Structural Engineering, 20(10), pp.1433-1450.

[8] Kaveh, A. and Eslamlou, A. D., 2017. Metaheuristic optimization algorithms in civil engineering: New applications. Cham: Springer International Publishing.

[9] Pavlović, S., 2018. Techno-economic analysis of castellated and solid I-profiled steel beams in terms of load capacity and serviceability. Савремена Теорија И ПРАКСА У ГРАДИТЕЉСТВУ, 13(1).

[10] Oukaili, N. K. and Abdullah, S. S., 2018, November. Strengthening Aspects to Improve Serviceability of Open Web Expanded Steel-Concrete Composite Beams in Combined Bending 
and Torsion. In IOP Conference Series: Materials Science and Engineering (Vol. 433, No. 1, p. 012041). IOP Publishing.

[11] Megharief, J. D., 1997. Behavior of composite castellated beams (Doctoral dissertation, McGill University).

[12] Al-Zuhairi, A. H., Mansi, A. I. and Anbar-Iraq, B. I., 2017, May. Behavior of composite concretecastellated steel beams in flexurell. In 1st International Conference on Recent Trends of Engineering Sciences Sustainability (Vol. 5).

[13] AISC Manual, 2017. Steel Construction Manual. 15th Ed. 